\title{
CAPITAL STRUCTURE AND BANK PERFORMANCE
}

\author{
Arie Widyastuti ${ }^{1}$, Ratna Komara ${ }^{2}$, Layyinaturrobaniyah ${ }^{3}$ \\ 1,2,3 Universitas Padjadjaran, Indonesia
}

\begin{abstract}
The decision of how firms finance their investments is among the prominent researchers in the area of corporate finance. The capital structure of banks, however, still relatively under-explored. Banking is one type of industry that employs a high level of leverage in creating companies' value since its operating profits come from lending and borrowing activities. This research aims to analyse the effect of the mix of capital structure on financial performance of commercial banks in Indonesia. We use annual data for the period $2009-2017$ that are extracted from the audited financial statement. The data is then analysed to find relationship on the use of leverage to the firms' performance. Our study finds strong evidence that short term loan significantly has positive influence on profitability of banks through Return on Equity (ROE), which indicates that deposit is considered as the cheapest source of funding. However, banks should carefully maintain their liquidity risk to ensure the availability of funds to pay for withdrawals obligation. We also found that the use of long-term debt and the use of equity, in general, do not have a significant effect on firm value, which indicates that, in terms of long-term financing, profitability and firm value are insensitive to capital structure.
\end{abstract}

Keywords: capital structure, leverage, profitability, firm's value

\section{STRUKTUR MODAL DAN KINERJA BANK}

\begin{abstract}
ABSTRAK
Salah satu topik penelitian yang sangat berkembang di area manajemen keuangan perusahaan merupakan analisis pendanaan. Namun demikian, penelitian mengenai struktur permodalan pada industry perbankan masih belum mendapatkan perhatian yang sama besarnya dengan struktur permodalan perusahaan pada industri non finansial, sementara industry perbankan merupakan industri dengan tingkat pendanaan hutang yang tinggi, karena karakteristik operasionalnya yang mengandalkan proses intermediasi antara pihak yang kelebihan dan pihak yang kekurangan dana. Penelitian ini bermaksud untuk menganalisis dampak struktur modal terhadap kinerja keuangan perbankan di Indonesia. Data yang digunakan dalam penelitian ini diambil dari laporan keuangan 23 bank di Indonesia yang terdaftar di Otoritas Jasa Keuangan selama periode 2009 - 2017. Dari hasil penelitian diperoleh bahwa pendanaan jangka pendek berpengaruh positive signifikan terhadap tingkat profitabilitas perbankan yang diukur menggunakan rasio Return on Equity (ROE), yang mengindikasikan penyaluran simpanan dan deposito sebagai sumber pendanaan murah dalam mengahasilkan pendapatan, Namun demikian perusahaan juga harus memastikan ketersediaan dana untuk meminimalisir risiko likuiditas. Penelitian ini juga menyimpulkan bahwa keputusan struktur modal tidak berpengaruh terhadap nilai perusahaan yang diukur menggunakan Tobin's $Q$, yang mendukung pendapat bahwa struktur pendanaan jangka panjang tidak berpengaruh terhadap penciptaan keuntungan dan penciptaan nilai perusahaan.
\end{abstract}

Kata-kata kunci: leverage, profitabilitas, nilai perusahaan, struktur modal.

Korespondensi: Arie Widyastuti, B.Buss., MIB. Faculty of Economics and Business Universitas Padjadjaran. Jln. Dipati Ukur No. 35 Bandung, Jawa Barat, Indonesia. Email: arie.widyastuti@fe.unpad.ac.id. 


\section{INTRODUCTION}

The existence of an efficient financial system is a prerequisite in enhancing the sustainable development of a nation. Financial institutions play the role of financial intermediation by collecting and mobilising resources to finance business and development projects that are essential to the growth of an economy. Although financial system incorporates a broad range of institutions that can be categorised into bank and non - bank financial institutions, currently in Indonesia, the Banking system dominates the sector for financial services. According to Indonesia Deposit Insurance Data, as per 2018 Indonesian banks still retained the largest asset, accounted for $\mathrm{Rp} 7.368$ trillion, with annual growth of $9,25 \%$. Therefore, it is important for Indonesian banks to be profitable in order to ensure economic development, as a failure of this sector could have adverse systemic effect on the entire economy.

Determining the optimal combination of debt and equity in maximizing the company's value has been a subject of empirical research. The financial crisis that is originated from the US subprime mortgage meltdown is considered to be the worst crisis for banking industry worldwide, and the evidence has shown the crisis to be caused by banks' excessive leverage (Ivashina \& Scharfstein, 2010).

Ever since the emergence of Modigliani and Miller (1958a) capital structure theorem, the use of leverage has been the focus of empirical researches in the field of corporate finance. What determines the capital structure of firms is still an intriguing question for economists and researchers. Despite the fact that this is a very well researched field, previous researches have mostly focused on non-financial firms, not many on that of financial institutions in general.

Flannery (1994) explains that the optimal structure for a firm's financial liabilities will influence its benefits of using leverage and will depend on the nature of the business. Banks, however, have significant variations in the operational systems with non - financial firms which result in significant differences in their capital structure. Banks are found to have significantly high leverage ratios as opposed to all companies operating in non-financial fields since their main function is to accumulate surplus funds and make them available to deficit sectors. They make profits through lending and borrowing activities, therefore unlike non-financial firms whose profitability and their exposure on bankruptcy costs influence their preference of debts, banks have less choice but must rely on debts, most of which comes from deposits as one of the major and cheapest sources of funds to ensure their smooth ongoing operation. Banks usually invest in assets that are more complicated to understand for the outsiders, and the information on their investment projects are expensive and difficult to evaluate. This will increase the cost of issuing equity due to information asymmetry problems, making banks prefer debt over equity. 
Furthermore, short term debts can help discipline the banks' managers to the risk of liquidity and mismatched maturities. Diamond and Rajan (2000) finds that in order to maintain their liquidity level, banks have a volatile capital structure as opposed to the non-financial firms that have a more stable capital mix. This volatility in their capital structure has enabled banks to channel loans that are less liquid while raising more deposits that have higher liquidity levels.

\section{LITERATURE REVIEW}

The Modigliani and Miller (1958b) theorem is one of the keystones for later theories contributing to extensive research on capital structure. The theorem that is referred as the irrelevance proposition suggests under perfect capital market, a firm's financing decision does not affect their value since value of the firm will depend on the income generated by its assets, not by how the assets are financed. Since then, subsequent theories have been developed by taking into account existence of several market imperfections such as agency conflicts, taxes, and market frictions.

The extensive research on the relationship between capital structure and firm performance has concluded mixed findings. These theories include the extended M\&M (1963), which considers corporate taxes in light of benefits brought by tax shields, where increasing leverage might enable a firm to increase its value by taking advantage of tax shields on debt. Later on static trade-off theory stated by Kraus and Litzenberger (1973) weigh such tax shields against the bankruptcy costs, thus although firm can profit from tax shields on debt, higher leverage might lead higher expected direct and indirect financial distress cost, which decreases a firm's value. Trade-off theory then concludes that the optimum financing mix is reached if the tax benefit obtained from leverage and the cost occurred from financial distress are balanced.

At a practical level, the relationship between capital structure and the financial performance of firms has been the subject of several studies since the influential work of Jensen and Meckling (1976) on Agency Theory. According to Agency theory, debt financing is used to monitor the conflict of interest that occurs between shareholders and managers, since debt will be act as a tool to discipline managers in aligning their goals to those of the shareholders. The use of leverage in financing business projects will force the managers to invest in profitable ventures, which in the end will benefit the shareholders. If they choose unprofitable investments and not able to pay the debt, then the bondholders will file for bankruptcy, and managers will lose their job. Hence according to Agency theory, higher leverage is expected to reduce managerial inefficiency and enhancing firms' value.

Other thoughts explaining the capital structure of the firm is the pecking order hypothesis that is popularized by Myers and Majluf (1984). This theory argues that firms have a preference order for different types of finance, since the use of debt financing may give signalling effect. According to the pecking order theory, firms prefer 
financing their operations from internally generated funds and use external debt only when retained earnings are insufficient in meeting company's needs. In the case that a firm is required to raise funds from outside, they prefer to issue debt first before considering the issue of equity, since issuing debt is less likely to send a negative signal to investors who will cause investor to sell their shares leading to a fall in the stock price of the firm. Shares issued could be interpreted that the stock is overvalued, and issuing new shares can create dilution of ownership. Firms are therefore preferred to issue debt rather than equity if internal finance is insufficient.

From the perspective of information asymmetry on bank financing, the bank deposit customers who are the investors do not have much information about their bank's future decision. Therefore Diamond and Rajan (2000) argue the possibility of premature liquidation of short term debt may act as an incentive to managers to make value-maximizing decisions that may increase the firms' performance. Using set of American data, Hadlock and James (2002) finds that corporations with high level of profitability use high level of leverage; and concluded that the level of leverage that a firm should commit itself depends on the flexibility with which the firm can adjust its debt usage should earnings power fall below its average interest cost. Berger and Di Patti (2006) also find that higher leverage ratio for banks is related to higher profit efficiency.

However, some significant findings also show contradicting result where the use of leverage on the capital structure has negative impact on financial performance. Booth, Aivazian, Demirguc-Kunt, and Maksimovic (2001) studied the data of the ten developing countries and found that debt ratios have negative correlation with profitability. Byoun and Xu (2013) and Moon, Lee, and Waggle (2015) also reported that large debtfree firms have higher profitability and generate positive abnormal returned compared to their levered counterparts.

Our research is an attempt to seek answers on whether debt financing associated with firm value. We attempt to study if there is a linkage between the level of debt and the performance of Indonesian Banks listed in the Indonesian Securities Exchange. We measure performance in terms of ROE and firm value with Tobin's Q.

The findings of our research show that deposit has a significant positive impact on banks' profitability.

Banks as intermediaries are generating profits through interest charged on loan against interest on the deposit. Our findings aligned with the research findings of Shleifer and Vishny (2010) that stated Banks make loans, securitize these loans, trade them in, or hold cash, and that banks borrow short term and accept the risk of having to liquidate their portfolio holdings at below fundamental values in bad times.

However, although deposit as a short-term loan is considered as the cheapest source of financing in creating firms' value, it also potentially creates maturity mismatch that might trigger possibility of running systematic risks. Our 
results are robust to panels of large size and small size firms.

\section{METHODS}

This study examines the relationship between capital structure and firm performance of commercial banks listed in the Indonesian Stock Exchange within nine years period, ranged from 2009 to 2017. Our sample covered the population of Banking sector during ten years period with 222 observations. In order to avoid the risk of distortion in the quality of the data, this study uses dataset taken from audited annual financial statements.

We define the relationship between firms' performance and the factors determining it at time $\mathrm{t}$ as follows:

$$
Y_{i t}=\alpha+\delta z_{i t}+\theta^{\prime} x+\epsilon_{i t}
$$

Where $\mathrm{y}$ is a measure of performance return on equity, return on asset and Tobin's Q; $z$ is the capital structure or leverage using the ratio of equity to asset (DPK1TA $\mathrm{it}_{\mathrm{it}}$ ), total long debt to asset ratio $\left(\mathrm{DPK}_{2} \mathrm{TA}_{\mathrm{it}}\right)$, and deposit to asset ratio (DPK3TA $A_{i t}$ ), $x$ is the vector of control variables, consisting of several factors traditionally believed to determine firm performance, the size of the firm (SIZE $E_{i t}$, Operational Expense Operational Revenue $\left(\mathrm{BOPO}_{\mathrm{it}}\right)$, and Capital Adequacy Ratio $\left(\mathrm{CAR}_{\mathrm{it}}\right)$.

We use ROA and ROE as proxies for profitability that reflects firm's performance and Tobin's Q to measure firm's value. Return on Asset (ROA) indicates how well the bank manager utilise the assets available to generate assets, thus higher ROA ratio indicates better performance. On the other hand, ROE measures how much the Bank is earning on its equity investment. Tobin's $Q$ is a measurement that combines market performance with book values. Tobin's Q that is greater than 1 may indicate that the market perceived the value of the companies is higher than their book values.

We use the firm's size, ratio of operational expense and operational revenue and capital adequacy ratio for the reasons as follows. Firm's size may influence performance since larger firms tend to enjoy economies of scale which may positively influence financial results. By the tradeoff theory, large firms with lower bankruptcy costs and more stable cash flow would have higher capacity for debt financing. This positive relationship between size and leverage is also concluded by Booth et al. (2001); (Jermias, 2008); Titman and Wessels (1988) and Frank and Goyal (2009).

Meanwhile, operational expenses will lower the profitability and hence, the value of the firm. The more efficient banks manage their expenses the more profitable they are (Olson \& Zoubi, 2011; Yin, Yang, \& Mehran, 2013). This negative relationship exists because improvements in management operating expenses (lower cost to asset ratio) will improve efficiency and eventually lead to higher profits.

Banks always have very high leverage compared to non-financial firms since their profits come from loans in the form of the interest-bearing deposit that needs to be managed properly. However, in general, banks with high capital ratios are considered safer than those with low capital 
ratios (Dietrich \& Wanzenried, 2014). The quality of capital possessed by a bank is an indication of the ability of a bank to operate appropriately, Dincer, Gencer, Orhan, and Sahinbas (2011) show that capital adequacy ratios have a positive relationship with the financial soundness of bank and a negative relationship with possible failure. Roman and Şargu (2013) also stated that capital adequacy is one of the most crucial indicators of the financial health of the banking sector because it guarantees the capacity of the sector to absorb the eventual losses generated by the manifestation of specific risks or macroeconomic imbalances.

\section{RESULTS AND DISCUSSION}

The data for this study involves 222 observations. The descriptive statistics for the variables computed from the financial statements are summarized in Table 1.

Table 1. Summary of Descriptive Statistics

\begin{tabular}{cccccccccc}
\hline & ROA & ROE & Tobins Q & DPK1 & DPK2 & DPK3 & LN Size & BOPO & CAR \\
& & & & & & & & & \\
\hline Obs. & 222 & 222 & 222 & 222 & 222 & 222 & 222 & 222 & 222 \\
Mean & 0,0176 & 0,1297 & 1,3011 & 0,1325 & 0,0589 & 0,7927 & 17,4130 & 0,8418 & 0,1848 \\
Std. Dev & 0,0205 & 0,3188 & 0,9869 & 0,0467 & 0,0617 & 0,0712 & 2,0642 & 0,2086 & 0,0772 \\
Min & $-0,1115$ & $-1,4248$ & 0,1156 & 0,0604 & 0,0001 & 0,5378 & 0,0140 & 0,0152 & 0,000 \\
Max & 0,0900 & 4,0286 & 5,7123 & 0,3236 & 0,7639 & 1,0596 & 20,8173 & 2,3520 & 0,7872 \\
\hline
\end{tabular}

Source: processed data (2019)

Table 2 presents the result with a return on equity (ROE) as the measure of the firm profitability. As shown in the table, there is positive relationship between long term debt to total asset and short term debt (represented by the ratio between the amount of deposit to total asset), with short term liability significantly influence return on equity.
Table 2. Regression Outputs for Return on Equity (Dependent Variable) as Performance Measure

\begin{tabular}{lrrr}
\hline & $\begin{array}{c}\text { Equation } \\
\mathbf{1}\end{array}$ & $\begin{array}{c}\text { Equation } \\
\mathbf{2}\end{array}$ & $\begin{array}{c}\text { Equation } \\
\mathbf{3}\end{array}$ \\
\hline Constant & $0.985^{* * *}$ & $1.011^{* * *}$ & -0.042 \\
& $(.001)$ & $(0.000)$ & $(0.929)$ \\
Equity to & -0.747 & & \\
Total Asset & $(0.266)$ & & \\
Long Term & & 0.296 & \\
Debt to & & $(0.355)$ & \\
Total Asset & & & $0.923^{* * *}$ \\
Deposit to & & & $(0.007)$ \\
Total Asset & & & 0.005 \\
& & & \\
Firm Size & -0.006 & -0.009 & $(0.692)$ \\
& $(0.660)$ & $(0.466)$ & $-0.697^{* * *}$ \\
Expenses & $-0.677^{* * *}$ & $-0.685^{* * *}$ & $(0.000)$ \\
Ratio & $(0.000)$ & $(0.000)$ & -0.351 \\
& -0.485 & $-0.862^{* * *}$ & \\
\hline
\end{tabular}


Jurnal Bisnis dan Manajemen, Volume 20, No. 2, September 2019, p. 136-144

\begin{tabular}{lrrr}
\hline $\begin{array}{l}\text { Capital } \\
\text { Adequacy }\end{array}$ & $(0.253)$ & $(0.002)$ & $(0.279)$ \\
$\begin{array}{l}\text { Ratio } \\
\text { Adjusted R }\end{array}$ & 0.182 & 0.181 & 0.205 \\
F Statistics & 13.325 & 13.206 & 15.237 \\
& $(0.000)$ & $(0.000)$ & $(0.000)$ \\
& & & \\
\hline
\end{tabular}

Source: processed data (2019)

The findings on Table 3 support the hypothesis that capital structure, especially deposit is a significant variable to increase the return on equity. The evidence is consistent with the findings of Shleifer and Vishny (2010) that banks, as pure profit maximisers, borrow short - term to engage in risky transactions when profitability is high. Our results also in line with findings by Flannery (1994), that in order to minimize agency cost and information asymmetry, banks prefer debt as a mechanism to discipline managers, hence short term debts can help discipline the banks' managers to the risk of liquidity and mismatched maturities. As to whether the capital structure can influence profitability through return on asset and Tobin's Q, we cannot find sufficient evidence to support the hypothesis. However our findings consistently find that operational expense has negative influence on profitability. This indicates that the higher the expense ratio, the poorer the performance, which aligns with the conclusions of Yin et al. (2013) and Olson and Zoubi (2011).
Table 3. Regression Outputs for Return on Assets (Dependent Variable) as Performance Measure

\begin{tabular}{|c|c|c|c|}
\hline & Equation 1 & Equation 2 & Equation 3 \\
\hline \multirow[t]{2}{*}{ Constant } & $0.068 * * *$ & 0.068 & $0.075 * * *$ \\
\hline & $(0.000)$ & $(0.000)$ & $(0.000)$ \\
\hline \multirow{2}{*}{$\begin{array}{l}\text { Equity to } \\
\text { Total Asset }\end{array}$} & -0.032 & & \\
\hline & $(0.203)$ & & \\
\hline \multirow{3}{*}{$\begin{array}{l}\text { Long Term } \\
\text { Debt to Total } \\
\text { Asset }\end{array}$} & & 0.001 & \\
\hline & & & \\
\hline & & $(0.933)$ & \\
\hline \multirow{2}{*}{$\begin{array}{l}\text { Deposit to } \\
\text { Total Asset }\end{array}$} & & & -0.007 \\
\hline & & & $(0.606)$ \\
\hline \multirow[t]{2}{*}{ Firm Size } & $0.001 * * *$ & 0.001 & 0.001 \\
\hline & $(0.007)$ & $(0.012)$ & $(0.026)$ \\
\hline \multirow{2}{*}{$\begin{array}{l}\text { Expenses } \\
\text { Ratio }\end{array}$} & $-0.081 * * *$ & $-0.082 * * *$ & $-0.081 * * *$ \\
\hline & $(0.000)$ & $(0.000)$ & $(0.000)$ \\
\hline \multirow{2}{*}{$\begin{array}{l}\text { Capital } \\
\text { Adequacy } \\
\text { Ratio }\end{array}$} & 0.003 & -0.012 & -0.016 \\
\hline & $(0.847)$ & $(0.220)$ & 0.193 \\
\hline Adjusted R2 & 0.730 & 0.728 & 0.728 \\
\hline \multirow[t]{2}{*}{ F Statistics } & 150.285 & 148.768 & 149.011 \\
\hline & $(0.000)$ & $(0.000)$ & $(0.000)$ \\
\hline
\end{tabular}

Source: processed data (2019)

Table 4 shows the regression outputs for Tobin's Q (dependent variable) as a performance measure. 
Jurnal Bisnis dan Manajemen, Volume 20, No. 2, September 2019, p. 136-144

Table 4. Regression Outputs for Tobin's Q (Dependent Variable) as Performance Measure

\begin{tabular}{|c|c|c|c|}
\hline & Equation 1 & Equation 2 & Equation 3 \\
\hline \multirow[t]{2}{*}{ Constant } & 1.419 & .348 & -.842 \\
\hline & $(0.253)$ & (0.719) & $(0.604)$ \\
\hline \multirow{2}{*}{$\begin{array}{l}\text { Equity to } \\
\text { Total Asset }\end{array}$} & 0.000 & & \\
\hline & $(0.223)$ & & \\
\hline \multirow{2}{*}{$\begin{array}{l}\text { Long Term } \\
\text { Debt to Total } \\
\text { Asset }\end{array}$} & & -1.249 & \\
\hline & & $(0.252)$ & \\
\hline \multirow{2}{*}{$\begin{array}{l}\text { Deposit to } \\
\text { Total Asset }\end{array}$} & & & 1.175 \\
\hline & & & $(0.317)$ \\
\hline \multirow[t]{2}{*}{ Firm Size } & 0.007 & $0.074 *$ & $0.081^{*}$ \\
\hline & 0.910 & 0.090 & 0.076 \\
\hline \multirow{2}{*}{$\begin{array}{l}\text { Expenses } \\
\text { Ratio }\end{array}$} & -0.230 & -0.241 & -0.301 \\
\hline & $(0.503)$ & $(0.482)$ & $(0.381)$ \\
\hline \multirow{2}{*}{$\begin{array}{l}\text { Capital } \\
\text { Adequacy } \\
\text { Ratio }\end{array}$} & -0.687 & -0.339 & 0.237 \\
\hline & $(0.472)$ & $(0.714)$ & $(0.833)$ \\
\hline Adjusted $\mathrm{R}^{2}$ & 0.028 & 0.010 & 0.008 \\
\hline \multirow[t]{2}{*}{ F Statistics } & 1.578 & 1.533 & 1.453 \\
\hline & 0.181 & 0.194 & 0.218 \\
\hline
\end{tabular}

Source: processed data (2019)

Table 4 shows the regression of different independent variables, consists of equity, long term debt and short term debt on firms value that is calculated using Tobin's Q score. None of the independent variables has a significant effect on the dependent variables, although beta coefficient for long term debt is negative, which indicates possibility of lower company's value with the increase of the use of long term debt.

\section{CONCLUSION}

The purpose of this research is to analyse the relationship between capital structure and banks' performance. The study analyse Banks institution listed in Indonesia Stock Exchange over nine years period and confirms that short term loan significantly has a positive impact on profitability of banks through Return on Equity (ROE). Our results are held for both small size and large size firms.

We also find that the relationship between capital structure and firms' value, measured by Tobin's Q, is minimal. This supports the view that the creation of firms' value is independent of the structure of financing activities. Hence the proportion of capital structure (the use of debt and equity) has no apparent on firm value and can be changed anytime. Therefore, there are other major factors that influence the value of the Indonesia banking sector other than its capital structure.

\section{REFERENCES}

Berger, A. N., \& Di Patti, E. B. (2006). Capital structure and firm performance: A new approach to testing agency theory and an application to the banking industry. Journal of Banking \& Finance, 30(4), 1065-1102.

Booth, L., Aivazian, V., Demirguc-Kunt, A., \& Maksimovic, V. (2001). Capital structures in developing countries. The Journal of Finance, 56(1), 87-130.

Byoun, S., \& Xu, Z. (2013). Why do some firms go debt free? Asia-Pacific Journal of Financial Studies, 42(1), 1-38.

Diamond, D. W., \& Rajan, R. G. (2000). A theory of bank capital. The Journal of Finance, 55(6), 2431-2465.

Dietrich, A., \& Wanzenried, G. (2014). The determinants of commercial banking profitability in low-, middle-, and high-income 
countries. The Quarterly Review of Economics and Finance, 54(3), 337-354.

Dincer, H., Gencer, G., Orhan, N., \& Sahinbas, K. (2011). A performance evaluation of the Turkish banking sector after the global crisis via CAMELS ratios. Procedia-Social and Behavioral Sciences, 24, 1530-1545.

Flannery, M. J. (1994). Debt maturity and the deadweight cost of leverage: Optimally financing banking firms. The American economic review, 84(1), 320-331.

Frank, M. Z., \& Goyal, V. K. (2009). Capital structure decisions: which factors are reliably important? Financial management, 38(1), 1-37.

Hadlock, C. J., \& James, C. M. (2002). Do banks provide financial slack? The Journal of Finance, 57(3), 1383-1419.

Ivashina, V., \& Scharfstein, D. (2010). Bank lending during the financial crisis of 2008. Journal of financial economics, 97(3), 319-338.

Jensen, M. C., \& Meckling, W. H. (1976). Theory of the firm: Managerial behavior, agency costs and ownership structure. Journal of financial economics, 3(4), 305-360.

Jermias, J. (2008). The relative influence of competitive intensity and business strategy on the relationship between financial leverage and performance. The British Accounting Review, 40(1), 71-86.

Kraus, A., \& Litzenberger, R. H. (1973). A statepreference model of optimal financial leverage. The Journal of Finance, 28(4), 911-922.

Modigliani, F., \& Miller, M. H. (1958a). The cost of capital, corporation finance and the theory of investment. The American economic review, 48(3), 261-297.

Modigliani, F., \& Miller, M. H. (1958b). The cost of capital, corporation finance and the theory of investment. The American economic review, 261-297.

Modigliani, F., \& Miller, M. H. (1963). Corporate income taxes and the cost of capital: a correction. The American economic review, 53(3), 433-443.

Moon, G., Lee, H., \& Waggle, D. (2015). The effect of debt capacity on the long-term stock returns of debt-free firms. Applied Economics, 47(4), 333345.

Myers, S. C., \& Majluf, N. S. (1984). Corporate financing and investment decisions when firms have information that investors do not have. Journal of financial economics, 13(2), 187-221.

Olson, D., \& Zoubi, T. A. (2011). Efficiency and bank profitability in MENA countries. Emerging markets review, 12(2), 94-110.

Roman, A., \& Şargu, A. C. (2013). Analysing the financial soundness of the commercial banks in Romania: an approach based on the camels framework. Procedia economics and finance, 6 , 703-712.

Shleifer, A., \& Vishny, R. W. (2010). Unstable banking. Journal of financial economics, 97(3), 306-318.

Titman, S., \& Wessels, R. (1988). The determinants of capital structure choice. The journal of finance, 43(1), 1-19.

Yin, H., Yang, J., \& Mehran, J. (2013). An empirical study of bank efficiency in China after WTO accession. Global Finance Journal, 24(2), 153170. 